\title{
How Relevant is Talent Management in South African Local Government Institutions?
}

\author{
Nicolene Barkhuizen (PhD) \\ Department of Industrial Psychology, North-West University, Mmabatho, South Africa, 2745 \\ nicolene.barkhuizen@nwu.ac.za
}

\section{Doi:10.5901/mjss.2014.v5n20p2223}

\begin{abstract}
Talent management is a concept increasingly on the minds of managers and practitioners, but still remain neither a strategic or operational priority in many organisations. The main objective of this research was to investigate the application of talent management practices in South African local government institutions $(N=578)$. The results showed that talent management practices are poorly applied in the local government institutions. Significant gaps exist between the current applications versus the importance of talent management practices. Significant differences exist between the employee perceptions of talent management practices based on their demographic characteristics. Recommendations are made.
\end{abstract}

Keywords: Talent management, local government institutions, service delivery, staff turnover, management commitment

\section{Introduction}

The South African public sector faces serious challenges relating to effective service delivery. Research continues to point out problems in the public service that lead to its failure to deliver quality services to the local population (Mabille \& Barkhuizen, 2013; Schutte \& Barkhuizen, 2014). This lack of poor service delivery is a direct result of talent management strategies that fail to retain key talent in the public service (Koketso \& Rust, 2012). Public service leadership should therefore give precedence to the talent management of skilled and competent staff as they are high in demand in the public sector.

Unfortunately, talent management is rarely a strategic or operational priority for many organisations. Research by the Human Capital Institute revealed that only $57 \%$ of companies surveyed had a department formally dedicated to talent management (Human Capital Institute, 2011). The results also showed that more than half of the companies stated that it is difficult to implement talent management practices. Furthermore the majority of the research studies to date shows that talent management practices are generally poorly applied within South African organisations (see Barkhuizen \& Stanz, 2010; Barkhuizen, Welby-Cooke, Schutte \& Stanz, 2014; Magolego, Barkhuizen \& Lesenyeho, 2013; Mtila, Barkhuizen \& Mokgele, 2013; Mpofu \& Barkhuizen, 2013; Theron, Barkhuizen \& Du Plessis, 2014). It is important to manage talented employees effectively as there are positive outcomes for all those involved. For individuals it leads to greater motivation, job satisfaction and work engagement (Magolego et al., 2013; Barkhuizen et al., 2014: Smith, 2014). At organisational level it increases service orientation and performance which in turn results in higher quality products and client satisfaction.

The main objective of this research was to determine the current application of talent management practices in South African local government institutions and whether significant differences exist between employee perceptions of talent management practices based on their demographic characteristics.

\subsection{Talent Management in the Public Sector}

The available literature shows that researchers differ greatly in their understanding of the concept of talent management (McDonnell, Lamare, Gunnigle \& Lavelle, 2010). Huang and Tansley (2012) further mention that talent management seem to be a highly contentious issue that requires further examination. The most commonly used definition of talent management involves the implementation of integrated human resource strategies to attract, develop, retain and productively utilise employees with the required skills and abilities to meet current and future business needs (Kontoghiorges \& Frangou, 2009). Applied within the public sector, we can refer to talent management as a concept that includes the attraction, training, development and retention of key employees while also taking into account the strategic goals of the client (Lockwood, 2005). 
Several researchers found that the application of talent management practices remains a significant problem for public sector institutions. A study by Koketso (2011) showed that employees leave local government institutions for better career development prospects elsewhere. These results are not surprising as almost $90 \%$ of the respondents in the sample indicated a mismatch between their knowledge, skills and job placement in local government. In addition participants were mostly frustrated by the lack of management support in terms of mentoring and coaching. A report by the Public Service Commission (2010) for example found that most of its public service managers are not competent in human resource functions such as compensation, recruitment and selection, performance management, organisational development safety and wellness. These practices are crucial for the effective management of a talented workforce in the public sector (Schuler, Tarique \& Jackson, 2011).

A study by Theron et al. (2014) in South African public higher education institutions revealed that academics are most likely to quit their jobs as a result of poor performance management and compensation practices. Another study by Barkhuizen et al. (2014) showed that talent management practices such as workforce planning, talent development and retention strategies were poorly applied among support staff in a public higher education institution and had a subsequent negative impact on their work engagement and service orientation.

Hypothesis 1: Talent Management practices are poorly applied in local government institutions

\subsection{Talent Management and Demographical variables}

Organisations are currently battling to balance the talent needs of different generations in the workplace. As Generation Y-ers or Millennials begin to enter the workforce, organizations are faced with new challenges as they try to find innovative solutions to attract and retain this group of employees (Du Plessis, Stanz \& Barkhuizen, 2010). It appears that once these individuals are employed, they are not likely to remain in that position for very long. Masibigiri and Nienaber (2011) found that factors such as work content, utilisation of skills, career advancement, work-life balance, compensation, security needs, leadership and drive influenced generation $Y$ public servants to remain in the organisation.

Job status can also impact on how talent management is perceived. Some studies have shown that significant differences exist between middle management, supervisory staff and operational staff in terms of how they view their organization's talent mindset (Barkhuizen \& Veldsman, 2012). In this study middle management perceived that the leaders of the company did not apply talent management practices as effectively compared to the rest of the management groups. Middle management was also more likely to leave the organisation because of the lack of commitment of executive management towards talent management. Another study among academics in South African public higher education institutions showed that talented individuals employed at higher job levels face more work demands than those employed on lower job levels (Nagel, 2013). The respondents in this sample experienced demands such as increased workloads as a result of poor staffing and talent acquisition at higher levels in the institution.

Hypothesis 2: Significant differences exist between the perceptions of talent management practices of local government employees based on their demographic backgrounds

\section{Research Design}

\subsection{Research Method}

The research approach of the present study was quantitative in nature as the aim was to explore the application of talent management practices in the South African public sector context. A non-experimental cross-sectional survey research strategy of inquiry was utilized in this study based on the need for exploratory research on talent management in South African local government institutions (Cresswell, 2009).

\subsection{Sampling}

The sample consisted of employees $(\mathrm{N}=578)$ from various local government institutions in South Africa. Nine hundred questionnaires were distributed with 578 questionnaires returned. This represents a $64.2 \%$ response rate. Most of the respondents in the sample were female (56.2\%), aged between 30 and 39 years (40.3\%) with a Grade 12 and Certificate as their highest level of qualification (49.7\%). The respondents were primarily employed on senior management level (31.1\%), with 0-10 years of work experience (61.2\%) and employed between 0-10 years in their current job (74.4\%). Respondents also indicated that they are working between 21 and 40 hours a week and had a maximum of 2 changes for promotion. The demographic breakdowns of the respondents are reported in the Table below. 
Table 1. Demographic characteristic of the respondents

\begin{tabular}{|c|c|c|c|}
\hline Item & Category & Frequency & Percentage \\
\hline \multirow{2}{*}{ Gender } & Male & 252 & 43.6 \\
\hline & Female & 325 & 56.2 \\
\hline \multirow{5}{*}{ Age } & $0-29$ & 124 & 21.5 \\
\hline & $30-39$ & 233 & 40.3 \\
\hline & $40-49$ & 160 & 27.7 \\
\hline & $50-59$ & 55 & 9.5 \\
\hline & 60 and more & 6 & 1.0 \\
\hline \multirow{3}{*}{ Qualification } & Matric to Certificate & 287 & 49.7 \\
\hline & Bachelors Degree & 256 & 44.3 \\
\hline & Post-graduate & 31 & 5.4 \\
\hline \multirow{4}{*}{ Job Level } & Senior Management & 180 & 31.1 \\
\hline & Middle Management & 127 & 22.0 \\
\hline & Supervisor & 108 & 18.7 \\
\hline & Operational Staff & 161 & 27.9 \\
\hline \multirow{4}{*}{ Years Work Experience } & $0-10$ & 354 & 61.2 \\
\hline & $11 .-20$ & 130 & 22.5 \\
\hline & $21-30$ & 37 & 6.4 \\
\hline & 30 years and more & 57 & 9.9 \\
\hline \multirow{4}{*}{ Years Current Job } & $0-10$ & 430 & 74.4 \\
\hline & $11 .-20$ & 98 & 17.0 \\
\hline & $21-30$ & 24 & 4.2 \\
\hline & 30 years and more & 25 & 4.3 \\
\hline \multirow{3}{*}{ Hours Work } & $0-20$ & 32 & 5.5 \\
\hline & $21-40$ & 329 & 56.9 \\
\hline & more than 40 & 216 & 37.4 \\
\hline \multirow{3}{*}{ Promotion } & $0-2$ & 443 & 76.6 \\
\hline & $3 .-4$ & 52 & 9.0 \\
\hline & 5 and more & 83 & 14.4 \\
\hline
\end{tabular}

\subsection{Measurements}

An adapted version of the Human Capital Index was used to assess the respondents' perceptions of Talent Management practices in local government institutions. The $\mathrm{HCl}$ consist of 37 items and measure eight Talent Management Practices: Management Commitment, Talent Review Process, Workforce Planning, Staffing, Talent Acquisition, Talent Development, Performance Management and Talent Retention. This measure uses a dual scale. Respondents are first requested to evaluate the current application of talent management practices in the organisation on a five-point Likert scale ranging from Poor (1) to Excellent (5). Second the respondents are required to indicate the importance of the Talent Management practices on a five-point scale ranging from Not (1) to Critical (5). Acceptable reliabilities were found for the measure in various South African studies (see Du Plessis et al. 2010; Mpofu \& Barkhuizen, 2013).

\subsection{Statistical Analyses}

Statistical analysis was carried out using the SPSS Program (SPSS, 2014). The reliability and validity of the $\mathrm{HCl}$ were determined by means of Cronbach alpha coefficients, as well as exploratory factor analysis. Multivariate analysis of variance (MANOVA) was used to determine the significance of differences between the levels of the talent management of demographic groups. When an effect is significant in MANOVA, ANOVA is used to discover which dependent variables are affected. In terms of statistical significance, a value at a 95\% confidence interval level $(p \leq 0,05)$ is set. Effect sizes (Field, 2009) were used to decide on the practical significance of the findings. Cohen's (1988, p. 283) guidelines for the interpretation of effect sizes: 0.0099 constitutes a small effect, 0.0588 a medium effect and 0.1379 a large effect was used to interpret the magnitude of the effect sizes. 


\section{Results}

\subsection{Factor and Reliability analyses}

The metric properties of the Human Capital Institute were first examined. These included the Kaiser-Meyer-Olkin (KMO) to determine the sample adequacy and sphericity of the item-correlation matrix, exploratory factor analysis to discover and identify the dimensions of the measurements and reliability analysis using Cronbach alpha coefficients to give the measure of accuracy of the instruments and to determine how repeatable the results are. The $\mathrm{HCl}$ obtained a Measure of Sampling Adequacy of 0.927 which according to the guideline of higher than 0.6 is adequate for factor analysis (see Hair, Black, Babin \& Anderson, 2010). Exploratory factor analysis using the Principal Component method was performed on the $\mathrm{HCl}$. Results revealed eight underlying factors for the $\mathrm{HCl}$ which explained $66.88 \%$ of the variance. These factors were labelled Talent Review Process (Factor 1), Management Commitment (Factor 2), Workforce Planning (Factor 3), Talent Retention (Factor 4), Staffing (Factor 5), Talent Development (Factor 6), Talent Acquisition (Factor 7) and Performance Management (Factor 8). Two items were deleted due to problematic loadings. The results of the rotated component matrix and items per factor are reported in Table 2 below. Each item showed acceptable loadings.

Table 2. Rotated Component Matrix of the $\mathrm{HCl}$

\begin{tabular}{|c|c|c|c|c|c|c|c|c|}
\hline & \multicolumn{8}{|c|}{ Components } \\
\hline & $\begin{array}{c}\text { Talent Review } \\
\text { Process }\end{array}$ & $\begin{array}{l}\text { Management } \\
\text { Commitment }\end{array}$ & $\begin{array}{l}\text { Workforce } \\
\text { Planning }\end{array}$ & $\begin{array}{c}\text { Talent } \\
\text { Retention }\end{array}$ & Staffing & \begin{tabular}{c|} 
Talent \\
Development
\end{tabular} & $\begin{array}{c}\text { Talent } \\
\text { Acquisition }\end{array}$ & \begin{tabular}{|l} 
Performance \\
Management
\end{tabular} \\
\hline $\mathrm{HCl} 1$ & .100 & .668 & .233 & .042 & .136 & .046 & .268 & $\begin{array}{l}.085 \\
\end{array}$ \\
\hline $\mathrm{HCl} 2$ & .125 & .847 & .188 & .071 & .107 & .163 & .131 & .059 \\
\hline $\mathrm{HCl} 3$ & .181 & .834 & .193 & .150 & .038 & .136 & .098 & .076 \\
\hline $\mathrm{HCl} 4$ & .154 & .754 & .169 & .243 & .107 & .113 & -.021 & .103 \\
\hline $\mathrm{HCl} 5$ & .220 & .698 & .262 & .171 & .052 & .159 & -.048 & .103 \\
\hline $\mathrm{HCl} 6$ & .671 & .267 & .109 & .114 & .153 & .231 & -.083 & .127 \\
\hline $\mathrm{HCl} 7$ & .781 & .210 & .208 & .077 & .104 & .093 & .087 & .087 \\
\hline $\mathrm{HCl} 8$ & .722 & .133 & .217 & .186 & .233 & .198 & -.031 & .028 \\
\hline $\mathrm{HCl} 9$ & .643 & .112 & .229 & .260 & .286 & .134 & .084 & .020 \\
\hline $\mathrm{HCl} 10$ & .658 & .136 & .235 & .113 & .297 & .163 & .141 & .046 \\
\hline $\mathrm{HCl} 11$ & .218 & .198 & .693 & .023 & .151 & .118 & .077 & .136 \\
\hline $\mathrm{HCl} 12$ & .156 & .170 & .662 & .059 & .094 & .140 & .167 & .078 \\
\hline $\mathrm{HCl} 13$ & .086 & .303 & .692 & .143 & .147 & .081 & .112 & .093 \\
\hline $\mathrm{HCl} 14$ & .163 & .267 & .702 & .208 & .088 & .099 & .128 & .083 \\
\hline $\mathrm{HCl} 15$ & .266 & .095 & .706 & .196 & -.006 & -.072 & .156 & .156 \\
\hline $\mathrm{HCl} 16$ & .262 & .154 & .164 & .152 & .711 & .102 & .001 & -.025 \\
\hline $\mathrm{HCl} 17$ & .214 & .185 & .165 & .080 & .761 & .097 & .015 & .016 \\
\hline $\mathrm{HCl} 18$ & .217 & -.150 & .162 & -.152 & .604 & -.015 & .305 & .243 \\
\hline $\mathrm{HCl} 19$ & .195 & .111 & -.009 & .035 & .586 & .258 & .192 & .178 \\
\hline $\mathrm{HCl} 20$ & .522 & .021 & .024 & .112 & .172 & .074 & .553 & .131 \\
\hline $\mathrm{HCl} 21$ & .095 & .178 & .369 & .041 & .071 & .054 & .690 & .142 \\
\hline $\mathrm{HCl} 22$ & -.085 & .154 & .363 & .133 & .178 & .227 & .573 & .069 \\
\hline $\mathrm{HCl} 23$ & .027 & .287 & .318 & .338 & .118 & .227 & .402 & .138 \\
\hline $\mathrm{HCl} 24$ & .303 & .274 & .017 & .228 & .207 & .600 & .139 & .113 \\
\hline $\mathrm{HCl} 25$ & .438 & .225 & .082 & .157 & .156 & .653 & .149 & .076 \\
\hline $\mathrm{HCl} 26$ & .326 & .105 & .114 & .097 & .156 & .729 & .159 & .012 \\
\hline $\mathrm{HCl} 27$ & -.171 & .146 & .380 & .130 & .186 & .387 & .024 & .428 \\
\hline $\mathrm{HCl} 28$ & .069 & .213 & .372 & .252 & .031 & .550 & -.067 & .297 \\
\hline $\mathrm{HCl} 29$ & .055 & .067 & .337 & .088 & .188 & .032 & .187 & .713 \\
\hline $\mathrm{HCl} 30$ & .231 & .239 & .147 & .271 & -.010 & .152 & .113 & .672 \\
\hline $\mathrm{HCl} 31$ & .401 & .153 & .001 & .162 & .424 & .175 & .105 & .460 \\
\hline $\mathrm{HCl} 34$ & .430 & .066 & -.076 & .538 & .199 & .094 & .354 & .098 \\
\hline $\mathrm{HCl} 35$ & .147 & .180 & .143 & .711 & .042 & .082 & .068 & .219 \\
\hline $\mathrm{HCl} 36$ & .181 & .185 & .245 & .763 & .072 & .123 & .083 & .100 \\
\hline $\mathrm{HCl} 37$ & .126 & .130 & .148 & .788 & .010 & .170 & -.003 & .022 \\
\hline
\end{tabular}

The descriptive statistics and reliabilities of the $\mathrm{HCl}$ are reported in Table 3 below. From Table 3 it is evident that all the factors show acceptable to very good reliabilities. From the results it is also clear that the respondents perceived that 
talent management practices are applied poorly in local government institutions. Some of the most problematic practices include a lack of talent retention strategies and workforce planning. The results also revealed a considerable lack of Management Commitment towards talent management in local government.

Table 3. Descriptive Statistics and Reliabilities of the $\mathrm{HCl}$

\begin{tabular}{|l|c|c|c|c|c|}
\hline & Mean & Std. Deviation & Skewness & Kurtosis & $\mathbf{\alpha}$ \\
\hline Management Commitment & 2.7080 & .97090 & .131 & -.641 & .898 \\
\hline Talent Review Process & 2.8266 & .94767 & .031 & -.680 & .886 \\
\hline Workforce Planning & 2.7215 & .85308 & .213 & -.093 & .856 \\
\hline Staffing & 3.0536 & .83608 & .079 & -.269 & .751 \\
\hline Talent Acquisition & 2.9909 & .78038 & -.014 & -.220 & .720 \\
\hline Talent Development & 2.9391 & .83901 & -.031 & -.429 & .801 \\
\hline Performance Management & 2.9458 & .84827 & -.044 & -.291 & .716 \\
\hline Talent Retention Strategies & 2.5355 & .91885 & .198 & -.597 & .810 \\
\hline
\end{tabular}

A further analysis was done to determine whether any significant differences exist between the respondents' perceptions of the current application versus the importance of talent management practices in local government. The results in Table 4 showed that large gaps exist between current applications of talent management practices compared with the importance thereof for respondents. Significant gaps were observed between Management Commitment, Workforce planning, Talent Acquisition and Talent Development. The above results confirm hypothesis 1 namely that talent management practices are poorly applied in local government institutions.

Table 4. Gap Analyses: Current application versus Importance of Talent Management Practices

\begin{tabular}{|l|c|c|c|c|}
\hline \multirow{2}{*}{} & \multicolumn{3}{|c|}{ Mean } & \\
\cline { 2 - 5 } & Current & Importance & Gap & $\boldsymbol{p}$ \\
\hline Management Commitment & 2.7080 & 3.6761 & -.96817 & .000 \\
\hline Talent Review Process & 2.8266 & 3.5609 & -.73426 & .553 \\
\hline Workforce Planning & 2.7215 & 3.5308 & -.80934 & .000 \\
\hline Staffing & 3.0536 & 3.6423 & -.58867 & .103 \\
\hline Talent Acquisition & 2.9909 & 3.8192 & -.82829 & .000 \\
\hline Talent Development & 2.9391 & 3.7865 & -.84740 & .008 \\
\hline Performance Management & 2.9458 & 3.5740 & -.62826 & .334 \\
\hline Talent Retention Strategies & 2.5355 & 3.7210 & -1.18555 & .275 \\
\hline
\end{tabular}

Next, MANOVA analyses was done to assess the relationship between the Talent Management dimensions and demographic variables, such as gender, age, educational qualification, job level, years of work experience, years in current job, hours work per week and promotion opportunities. The results in Table 5 showed that significant differences exist in the employee perceptions of the current application of talent management practices based on all their demographic characteristics except for years in current job. Further post-hoc analyses revealed no significant differences for gender perceptions of talent management practices. The post-hoc analyses are reported below.

Table 5. Manova Analyses: Talent Management and Demographic variables

\begin{tabular}{|l|c|c|c|c|c|c|}
\hline & Value & $\mathbf{F}$ & Hypothesis df & Error df & Sig. & Partial Eta Squared \\
\hline Gender & .970 & $2.188^{\mathrm{b}}$ & 8.000 & 568.000 & .027 & .030 \\
\hline Age & .911 & 1.667 & 32.000 & 2088.900 & .011 & .023 \\
\hline Educational Qualification & .905 & $3.605^{\mathrm{b}}$ & 16.000 & 1128.000 & .000 & .049 \\
\hline Job Level & .859 & 3.669 & 24.000 & 1639.273 & .000 & .049 \\
\hline Years Work Experience & .889 & 2.850 & 24.000 & 1645.074 & .000 & .039 \\
\hline Years Current Job & .950 & 1.222 & 24.000 & 1642.173 & .210 & .017 \\
\hline Hours work per week & .906 & $3.598^{\mathrm{b}}$ & 16.000 & 1134.000 & .000 & .048 \\
\hline Promotion Opportunities & .953 & $1.747^{\mathrm{b}}$ & 16.000 & 1136.000 & .034 & .024 \\
\hline
\end{tabular}

The Wilks' Lambda for age is equal to $0.911[F(32,2088.900)=1.667, p \leq 0.05]$. Analysis of each dependent variable, using a Bonferroni adjusted alpha level of 0,025 , showed that the age differ in terms of Talent Retention Practices $\left(F_{(4,578)}\right.$ $=3.067, p \leq 0,05$, partial $\eta^{2}=.021$ ). Employees aged between $20-29$ years perceived that talent retention strategies are more effectively applied compared to employees aged between 30 and 39 years of age. The effects are small. 
The Wilks' Lambda for educational qualification is equal to $0.905\left[F(16,1128)=3.605^{\mathrm{b}}, p \leq 0.05\right]$. Analysis of each dependent variable, using a Bonferroni adjusted alpha level of 0,025 , showed that the respondents differ in terms of Talent Review Process $\left(F_{(2,578)}=11.052, p \leq 0,05\right.$, partial $\left.\eta^{2}=.037\right)$, Staffing $\left(F_{(2,578)}=7.088, p \leq 0,05\right.$, partial $\left.\eta^{2}=.024\right)$ and Talent Development $\left(F_{(2,578)}=4.274, p \leq 0,05\right.$, partial $\left.\eta^{2}=.015\right)$. Employees with a bachelor's degree experienced less effective talent review processes compared to employees with post-graduate qualifications and employees with qualifications ranging from matrix to certificate. Employees with a post-graduate qualification experience more effective staffing practices compared to employees with a bachelor's degree. Employees with a bachelor's degree experience poorer staffing and talent development practices compared to employees with post-graduate qualifications. The effects are small.

The Wilks' Lambda for job level is equal to $0.859[F(24,1639.273)=3.669, p \leq 0.05]$. Analysis of each dependent variable, using a Bonferroni adjusted alpha level of 0,025 , showed that the respondents differ in terms of Management Commitment $\left(F_{(3,578)}=8.248, p \leq 0,05\right.$, partial $\left.\eta^{2}=.041\right)$. Senior Management experienced a higher level of management commitment towards talent management than compared to the rest of the job levels. The effects are small.

The Wilks' Lambda for years work experience is equal to $0.889[F(24,1645.074)=2.850, p \leq 0.05]$. Analysis of each dependent variable, using a Bonferroni adjusted alpha level of 0,025 , showed that the respondents groups differed in terms of Management Commitment $\left(F_{(3,578)}=3.068, p \leq 0,05\right.$, partial $\left.\eta^{2}=.016\right)$, Talent Acquisition Process $\left(F_{(3,578)}=\right.$ 2.801, $p \leq 0,05$, partial $\left.\eta^{2}=.014\right)$ and Talent Retention Practices $\left(F_{(3,578)}=3.610, p \leq 0,05\right.$, partial $\left.\eta^{2}=.019\right)$. Employees with 0-10 years of work experienced more management commitment towards talent management and talent retention practices than those employed for 30 years and more in the organisation. Employees with 0-10 years work experience perceived poorer talent acquisition than those employed 11 to 20 years. Employees with more than 30 years of work experience perceived less talent retention practices than those employed between 0-10 years.

The Wilks' Lambda for hours per week is equal to $0.906\left[F(16,1134)=3.598^{b}, p \leq 0.05\right]$. Analysis of each dependent variable, using a Bonferroni adjusted alpha level of 0,025 , showed that the ethnic groups differ in terms of Management Commitment $\left(F_{(2,578)}=16.048, p \leq 0,05\right.$, partial $\left.\eta^{2}=.048\right)$, Talent Review Process $\left(F_{(2,578)}=14.391, p \leq\right.$ 0,05 , partial $\left.\eta^{2}=.048\right)$, Staffing $\left(F_{(2,578)}=6.985, p \leq 0,05\right.$, partial $\left.\eta^{2}=.024\right)$, Talent Acquisition $\left(F_{(2,578)}=5.318, p \leq\right.$ 0,05 , partial $\left.\eta^{2}=.018\right)$, Talent Development $\left(F_{(2,578)}=7.482, p \leq 0,05\right.$, partial $\left.\eta^{2}=.025\right)$, Performance Management $\left(F_{(2,}\right.$ $578)=5.545, p \leq 0,05$, partial $\left.\eta^{2}=.019\right)$ and Talent Retention $\left(F_{(2,578)}=11.541, p \leq 0,05\right.$, partial $\left.\eta^{2}=.039\right)$. Employees working between 20 to 40 hours in a week perceived more management commitment to talent management practices and better talent review processes than those working between 0-20 hours and more than 40 hours a week. Employees working between 20 to 40 hours a week experienced better staffing, talent acquisition practices, talent development, performance management and talent retention practices than those working for more than 40 hours a week. Employees working between 20 to 40 hours in a week perceived better staffing practices than those working between $0-20$ hours in a work week.

The Wilks' Lambda for promotion opportunities is equal to $0.953\left[F(16,1136)=1.747^{\mathrm{b}}, p \leq 0.05\right]$. Analysis of each dependent variable, using a Bonferroni adjusted alpha level of 0,025 , showed that the respondents differ in terms of Talent Review Processes $\left(F_{(2,578)}=4.251, p \leq 0,05\right.$, partial $\left.\eta^{2}=.015\right)$, Staffing $\left(F_{(2,578)}=6.554, p \leq 0,05\right.$, partial $\eta^{2}=$ $.022)$ and Talent Retention Practices $\left(F_{(2,578)}=4.689, p \leq 0,05\right.$, partial $\left.\eta^{2}=.016\right)$. Those promoted between 3 to 4 times perceived better staffing processes and talent retention practices than those promoted between 0 to 2 times and 5 times and more. Those promoted between 3 to 4 times perceived talent review processes and than those promoted 5 times and more. The above results confirm hypothesis 2 namely that significant differences exist in the perceptions of the talent management practices of employees in local government institutions based on their demographic backgrounds.

Table 6 below provides a summary of the Talent Management practices as it relates to the demographic characteristics of the respondents.

Table 6. Summary of Talent Management practices and demographic variables

\begin{tabular}{|l|c|c|c|c|c|c|c|c|}
\hline & $\begin{array}{c}\text { Talent Review } \\
\text { Process }\end{array}$ & $\begin{array}{c}\text { Management } \\
\text { Commitment }\end{array}$ & $\begin{array}{c}\text { Workforce } \\
\text { Planning }\end{array}$ & $\begin{array}{c}\text { Talent } \\
\text { Retention }\end{array}$ & Staffing & $\begin{array}{c}\text { Talent } \\
\text { Development }\end{array}$ & $\begin{array}{c}\text { Talent } \\
\text { Acquisition }\end{array}$ & $\begin{array}{c}\text { Performance } \\
\text { Management }\end{array}$ \\
\hline Age & & & & $\mathrm{X}$ & & & & \\
\hline Educational Qualification & $\mathrm{X}$ & & & & $\mathrm{X}$ & $\mathrm{X}$ & & \\
\hline Job Level & & $\mathrm{X}$ & & & & & & \\
\hline Years Work Experience & & $\mathrm{X}$ & & $\mathrm{X}$ & & & $\mathrm{X}$ & \\
\hline Hours work per week & $\mathrm{X}$ & $\mathrm{X}$ & & $\mathrm{X}$ & $\mathrm{X}$ & $\mathrm{X}$ & $\mathrm{X}$ & $\mathrm{X}$ \\
\hline Promotion Opportunities & $\mathrm{X}$ & & & $\mathrm{X}$ & $\mathrm{X}$ & & & \\
\hline
\end{tabular}




\section{Discussion and Conclusion}

The main objective of this research was to explore the application of talent management practices in local government institutions. In addition this research also aimed at determining whether significant differences exist in local government employees' perceptions of talent management practices based on their demographic characteristics.

The results of the research confirmed previous studies which indicated that talent management practices are not receiving sufficient attention in the public sector (see Barkhuizen et al., 2014; Koketso, 2011; Koketso \& Rust, 2012; Masibigiri \& Nienaber, 2011; Theron et al., 2014). All the talent management practices in this study were poorly applied in the local government institutions investigated. Some of the most problematic talent management practices included poor workforce planning and talent retention strategies. In line with the findings of Koketso (2011) and the Public Service Commission report (2010), the results still showed a lack of management commitment towards talent management practices in local government. Significant gaps were observed between the current application versus the importance of talent management practices such as management commitment, workforce planning, talent acquisition and talent development.

As with previous studies the results also showed that respondents differed significantly in terms of their perceptions of the application of talent management practices in local government based on their demographic characteristics (see Barkhuizen \& Veldman, 2012; Nagel, 2013). Employees with postgraduate qualifications and employed on senior management level experienced that talent management practices are more effectively applied compared to their counterparts with only a bachelors' degree and employed on lower levels in the organisation. In addition respondents who are employed between 0-10 years in the institution experienced a more efficient application of talent management compared to those employed for more than 10 years. Further employees working for more than 40 hours a week experienced were dissatisfied with the current application of talent management compared to those who work between 20 and 40 hours per week.

Employees aged between 20 and 29 years perceived that talent retentions strategies are more efficiently applied compared to employees aged between 30 and 39 years of age. One possible explanation for this finding is that management may put in more effort to retain younger employees as they are more likely to leave organisations compared to other generations (see Du Plessis et al. 2010; Masibigiri \& Nienaber, 2011).

This research makes a contribution on theoretical, methodological and practical level. From a theoretical perspective this research adds to the limited empirical knowledge that currently exist on talent management in Subsaharan Africa and particularly local government institutions. This research contributed to the further validation of the Human Capital Index in the South African context. Finally this research also identified the problematic areas relating to talent management in local government institutions. Management in local government institutions can use these findings and develop interventions to improve talent management in local government.

The research had some limitations. First the sample was limited to local government institutions only. The results of the research can therefore not be generalised to other public sector organisations and the private sector. Second a cross-sectional research design was used which limits the research in terms of cause and effect inferences that can be made in terms of talent management practices in local government. Longitudinal studies can be used in line with other antecedent (i.e. organisational climate, human resource strategy) and outcome variables (i.e. service delivery, performance) to track the efficient application of talent management practices in local government.

In conclusion this research highlighted the meagre application of talent management in local government. The results clearly showed that local government institutions lack strategic focus with the application of talent management practices in the workplace. For example, talent retention practices are mostly concentrated around younger generations whilst ignoring the skilled, competent and more experienced older generations. These individuals possess a wealth of knowledge and experience that are irreplaceable when they leave organisations. The results also showed that poor talent management practices increase employee working hours which in turn can lead to poor individual and organisational performance.

Therefore it is recommended that the local government institutions review the current application of talent management and develop interventions and practices to attract and retain its talented employees. Local government institutions have a significant role to play in the creating and maintaining quality service to the population of South Africa. However without critical, key and scare talent local government cannot achieve its performance targets which a detrimental to South Africa as a developing country. 


\section{References}

Barkhuizen, E.N., Mogwere, P., \& Schutte, N.E. (2014). Talent Management, Work Engagement and Service Quality Orientation of Support Staff in a Higher Education Institution. Mediterranean Journal of Social Sciences, 5, 4, 69-77.

Barkhuizen, E.N., Welby-Cooke, G., Schutte, N.E., \& Stanz, K.J. (2014). Talent Management and Leadership Reciprocity: The case of the South African Aviation Industry. Mediterranean Journal of Social Sciences, 5, 9, 11-17.

Cohen, J. (1988). Statistical power analysis for the behavioral sciences (Revised ed.). Orlando, FL: Academic Press.

Cresswell, J. W. (2009). Research Design: Qualitative, Quantitative and Mixed Methods Approaches (3rd Ed.). Thousand Oaks: Sage Publications.

Du Plessis, L., Stanz, K., \& Barkhuizen. (2010). The relationship between Perceived talent management practices, Perceived Organizational Support (POS), Perceived Supervisor Support (PSS) and Intention to quit amongst Generation $Y$ employees in the Recruitment Sector. Paper presented at the 3rd Annual People and Organization's Conference, Wharton School, McGill University.

Field, A. (2009). Discovering statistics using SPSS (3rd ed.). London: Sage.

Goff, S. (2008). Finding, Developing and Managing Project Talent: In Today's Top Enterprises, Everyone's a Talent Scout. www.ProjectExperts.com

Hair, J. F., Black, W. C., Babin, B. J., \& Anderson, R. E. (2010). Multivariate data analysis: a global perspective (7th Ed). New Jersey: Pearson Education.

Huang, J., \& Tansley, C. (2012). Sneaking through the minefield of talent management: the notion of rhetorical obfuscation. International Journal of Human Resource Management, 23, 3673-3691.

Human Capital Institute (2011). Human Capital Institute Stakeholder Survey.

lles, P., Preece, D., \& Chuai, X. (2010). Talent Management as a management fashion in HRD: towards a research agenda. Human Resource Development International, 13, 2, 125-145.

Koketso, L.P. (2011). Perceived challenges to talent management in the South African public service: An exploratory study of the City of Cape Town municipality. Unpublished Masters Dissertation. Cape Peninsula University of Technology.

Koketso, L.P. \& Rust, A.A.B. (2012). Perceived challenges to talent management in the South African public service: An exploratory study of the City of Cape Town municipality. African Journal of Business Management, 6, 6, 2221-2233

Kontoghiorghes, C. \& Frangou, K. (2009). The association between talent retention, antecedent factors and consequent organizational performance. SAM Advanced Management Journal, 74, 1, 29-58.

Lockwood, N. (2005). Talent Management Overview. Alexandria, VA: Society of Human Resource Management.

Mabille, T., Barkhuizen, E.N., (2013). An Analysis of Municipal Financial Management in South Africa. In N. Delener, L. Fuxman, F. Lu, S. Rodrigues \& L. Rivera (Eds.), 15th Annual International Conference on Globalizing Businesses for the Next Century: Visualizing and Developing Contemporary Approaches to Harness Future Opportunities, Global Business and Technology Association, Helsinki, Finland (pp. 564-570), ISBN: 1-932917-08-X. USA, Gbata.

Magolego. H., Barkhuizen, E.N. \& Lesenyeho, D.L. (2013). Talent Management and Job Performance: The Mediating Role of Job Satisfaction. In S.M. Lee \& G. Roodt (Eds.), 30th Pan Pacific Conference, Johannesburg, South Africa (pp. 132-135), ISBN: 1931649-27-3. PPBA

Masibigiri, V., \& Nienaber, H. (2011). Factors affecting the retention of Generation X public servants: An exploratory study. SA Journal of Human Resource Management/SA Tydskrif vir Menslikehulpbronbestuur, 9, 1, 1-11.

McDonnell, A., Lamare, R., Gunnigle, P., \& Lavelle, J. (2010). Developing tomorrow's leaders - Evidence of global talent management in multinational enterprises. Journal of World Business, 45, 150-160.

Mpofu. L., \& Barkhuizen, E.N. (2013). The Impact of Talent Management Practices on Employees in a Government Institution. In S.M. Lee \& G. Roodt (Eds.), 30th Pan Pacific Conference, Johannesburg, South Africa (pp. (129-131) ISBN: 1-931649-27-3. PPBA.

Mtila, J., Barkhuizen, E.N., \& Mokgele, Mokgele, R. (2013). Exploring the Application of Talent Management Practices in a Local Government Institution. In S.M. Lee \& G. Roodt (Eds.), 30th Pan Pacific Conference, Johannesburg, South Africa (pp. 66-68) ISBN: 1-931649-27-3. PPBA.

Preece, D., lles, P., \& Chuai, X. (2011). Talent Management and management fashion in Chinese enterprises: exploring case studies in Beijing. The International Journal of Human Resource Management, 22, 16, 3413-3428.

Public Service Commission (2010). Assessment of the State of Human Resource Management in the South African public service. Red Flag Design and Marketing. ISBN: 978-0-621-39183-1

Schuler, R.S., Jackson, S.E., \& Tarique, I. (2011). Global Talent Management and global talent challenges: Strategic opportunities for IHRM. Journal of World Business, 46, 505-516.

Schutte, N.E., \& Barkhuizen, E.N. (2014). Creating Public Service Excellence Applying Learning Organisation Methods: The Role of Strategic Leadership. Mediterranean Journal of Social Sciences, 5, 4, 159-165.

Smit, A. (2014). The relationship between talent management, motivation and service orientation of support staff in a higher education institution. Unpublished Masters Dissertation, Polytechnic of Namibia

Theron, M., Barkhuizen, E.N., \& Du Plessis, Y. (2014). Managing the academic talent void: Investigating factors in academic turnover and retention in South Africa. South African Journal of Industrial Psychology, 40, 1, 1-14. 